\title{
Fiscal and Monetary Policies Coordination Rwanda Experience

\begin{abstract}
| Augustin Ndarihoranye ${ }^{1}$ | Gedion Alang' $0^{2, *} \mid$ Omwono $^{2}$ |
${ }^{1}$ Student of Post Graduate, Master's Degree of Science in Economics, University of Kigali, Rwanda

${ }^{2}$ Lecturer of Post Graduate, Master's Degree of Science in Economics, University of Kigali, Rwanda

*gedion.impact@gmail.com

ABSTRACT

This paper attempts to quantify the coordination between monetary and fiscal policies in Rwanda from 2008 to 2018. The paper uses Granger causality test and vector autoregressive (VAR) framework to determine whether these policies are implemented independently and also looks at the extent of their coordination. The empirical results using unstructured VAR model suggest that monetary and fiscal policies interact and are coordinated in $R$ wanda. The impulse response functions demonstrate significant interaction between monetary and fiscal policy. For instance a positive shock on government expenditure induces an increase in broad money that in turn induces an increase in liquidity in the economy. Finally, the paper recommends that both policies should continue interacting in order to strengthen policy coordination. Therefore, ultimately achieve a stable and low inflation together with high growth.

KEYWORDS

Monetary-fiscal policy coordination; VAR
\end{abstract}

\section{INTRODUCTION}

Fiscal and monetary policies are tools policymakers use either independently or in combination to direct changes in national economy. Although both authorities are independently responsible for their respective areas of policy, they work within a framework which takes into consideration the actions of the other. Generally, several economic scholars in their theoretical and empirical studies relate these policies as they operate interdependently to ensure stability of the economy. However, several results of these studies further sum up that the degree of effectiveness vary depending on the country's economic priorities Mohammed et al (2010).

In fact, the relative effectiveness of fiscal and monetary policies in stabilizing demand pressures requires a coordinated effort of both policies to deal with huge fiscal deficits and high inflationary pressures. Mohammad et al., (2010) says in his study that these policies are dependent to each other and pursuing only one policy without considering the other may not produce the desired results. This implies that lack of good policy coordination in the management of the economy may cause economic distortions even when policies seem strategically oriented to achieving their respective objectives.

Nordhaus (1994) postulated that under certain assumptions, countries may suffer huge budget deficits and higher real interest rates than expected when fiscal and monetary authorities operate independently. This may happen especially when fiscal authorities are reluctant towards reducing spending decisions. As result, financing of such deficits tend to deviate inflation developments away from their policy targets. In another study by Shabbir \& Ahmed (1994) noted that fiscal deficits directly affect inflation through viable transmission channel of price expectations. 
However, in poorly coordinated macroeconomic environment, monetary policy has remained passive to fiscal policy. In this regard, fiscal policy directly affects monetary policy through substantial increases in indirect tax rates, which have direct impact on inflation. The fiscal measures also indirectly affect the aggregate demand via their impact on monetary variables such as interest rates, interest rate spreads and exchange rate. Albeit the fiscal expansion is not monetized, the persistence of higher deficits may instigate the increase in net credit demands, driving up interest rates and crowding out private sector investment.

In view of the above, Sargent \& Wallace (1981) establish that high inflation and inflation expectations result when fiscal authorities set their expansionary spending objectives that ultimately need to be monetized independently of public sector liabilities. In an amended version of their model, they note that where fiscal policy is unsustainable, monetary authority loose its ability to control inflation.

In this regard, in its mandate to support the Government's macroeconomic policies, the central bank adopted a collaborative strategy with the government to provide a clear pathway for pursuing a consistent policy mix. Thus, the BNR is liaised with the Ministry of Finance and Economic Planning (MINECOFIN) through Treasury Management Committee (TMC) and Debt Management Committee (DMC). The TMC serves as an analytical platform for refining policy implementation and forecasts. This framework has quite significantly improved the basic nature of the interaction between monetary and fiscal authorities.

Under this context, in Rwanda, the law no 55/2007 of 30/11/2007 governing the National Bank of Rwanda sanctions the Central Bank as a national institution with legal personality and independence in operational, administrative and financial areas. The Bank preserves this autonomy in pursuit of macroeconomic missions. However, fiscal discipline is required for achieving the objectives of the monetary and exchange rate policy. Unsound fiscal policy usually create expectations leading to political pressures on the Bank to either accommodate higher inflation or lower interest rate in order to lessen the debt of the Government sector.

Law no 48/2017 of 23/09/2017 governing the National Bank of Rwanda (NBR) sanctions the Central Bank as a national institution with legal personality and independence in operational, administrative and financial areas. This law assigns to the NBR responsibility of formulating and implementing monetary policy by ensuring low and stable inflation. However, fiscal discipline is required for achieving this primary objective because unsound fiscal policies usually create expectations leading to political pressures on the central banks to either accommodate higher inflation or lower interest rate in order to lessen the debt of the Government sector.

Macroeconomic framework consists of formulation and monitoring of macroeconomic policies including issues relating to analysis and projections. The four core macroeconomic sectors; real sector, fiscal sector, monetary sector and external sector and subsequent policies such as debt policy compel central banks and governments to work closely.

To support the Government's macroeconomic policies, NBR adopted a collaborative strategy with the Ministry of Finance and Economic Planning (MINECOFIN(2017) to provide a clear pathway for pursuing a consistent policy mix. Thus, the NBR is liaised with MINECOFIN through Treasury Management Committee (TMC) and Debt Management Committee (DMC). The TMC serves as an analytical platform for refining policy implementation and forecasts, while DMC considers future issuance, including the balance between overdraft, bill issuance and bond issuance. 
High levels of coordination implies a reduction of policy conflicts that could result in the economy operating at a lower than optimal level, and a greater ability to respond to adverse external shocks, as well as sustainable growth path alongside low inflation, and an overall improvement in the economic well-being of citizens of the country. Likewise, in poorly coordinated macroeconomic environment, monetary policy has remained passive to fiscal policy (Farooq Arby 2010)

Rwanda's fiscal and monetary policy coordination focuses on different areas including: supply shocks, treasury management and investments in treasury bills. The central bank also participates in the issuing and distribution of treasury securities, transactions relating to public debt servicing, negotiation of securities, as well as the issue of advance to government.

Despite vast literature on the coordination between fiscal and monetary policies in developing countries. To the best of my knowledge, there is not a single study that has attempted to assess monetary-fiscal policy coordination in Rwanda. This paper therefore attempts to evaluate to what the extent fiscal and monetary policies are coordinated in Rwanda over the period 2008- 2018. Literature has shown that empirical result on this matter have been so far mixed and this study attempts to shed light on this issue by providing empirical estimates for the case of Rwanda.

The rest of the paper is organized as follows: Section 2 explores literature review, Section 3 reviews some stylized facts about the coordination between monetary and fiscal policies in Rwanda while section 4 describes the methodology used to assess the extent of the coordination between the monetary and fiscal policies. Section 5 consists of presentation and discussion of the results and finally section 6 is about the conclusion and recommendations

\section{RESEARCH METHODS}

This is paper attempts to quantify to what extent the fiscal and monetary policy are coordinated in Rwanda, To achieve this objective, we borrowed the methodology by Andlib et al (2012) in Pakistan who used unrestricted VAR model which consists of four variables: unemployment or output gap, inflation interest rate and fiscal balance. For this case, repo and broad money are used as monetary variables while government expenditure, public domestic debt and fiscal deficit/ GDP are used on the side of fiscal policy based on the nature of our fiscal and monetary policy framework.

Before we examine the extent of coordination, it makes sense to test empirically the independence of monetary policy from fiscal policy because the coordination arises the two institutions charged with the respective policies are operationally independent. In this regard, we apply Granger causality test borrowed from Andlib et al (2012), on a combination of monetary and fiscal policy indicators.

The study follows a VAR model to chart out the way policies have behaved over the period of analysis, and we perform a VAR for five variables categorized according to respective policies for the period 2008 Q1-2018 Q4.

Since their introduction by Sims (1980), the VAR models are arguably among the most popular models to analyze the macroeconomic dynamics, the greatest advantage being the possibility to observe the macroeconomic system following a shock to the other variables IV.1 Model specification

A VAR consists of a set of $\mathrm{n}$ endogenous variables $Y_{t}=\left(Y_{1 t}, Y_{2 t} \ldots \ldots Y_{n t}\right)$ and the VAR process is defined as $Y_{t}=\mu+A_{1} Y_{t-1}+A_{2} Y_{t-2}+\cdots \ldots \ldots+A_{p} Y_{t-p}+\varepsilon_{t}$

Where Ai are $n \times n$ coefficients matrices for $\mathrm{i}=1, \ldots \ldots \mathrm{p}$ and $\varepsilon_{t}=\left(\varepsilon_{1 t}, \varepsilon_{2 t} \ldots \ldots \varepsilon_{n t}\right)$ is an unobservable $\mathrm{n}$ dimensional error process. 
Our simple VAR model consists of a set of 5 variables namely M3, GOV, PUB, FISC and $r$ Where M3 represents broad money, GOV represents government expenditure, FISC represents fiscal balance, PUB represents domestic public debt and $\mathrm{r}$ represents interest rates especially repo rate.

To quantify to what extent the fiscal and monetary policies are coordinated, we analyze the responses of the different variables by using the Impulse Response Function from the VAR model. This method enables us to capture how fiscal and monetary variable respond to each other from their shocks.

\section{RESULTS AND DISCUSSION}

As described in literature and methodology we have variables on fiscal side as well as monetary variables. Government expenditure, public domestic debt and fiscal balance are used as fiscal variable while repo rate and broad money are used as monetary variables. The data were obtained from the National Bank of Rwanda reports and ministry of finance and economic planning

Normally, it is essential to ascertain the stationarity of variables before proceeding to other empirical tests. In this paper the researcher used the Augmented Dickey-Fuller test to check for null hypothesis of non-stationarity and to determine the order of integration of variables as in table below.

Table 1. Stationarity tests

\begin{tabular}{lcllll}
\hline \multirow{2}{*}{ Variables } & $\begin{array}{c}\text { ADF test statistic } \\
\text { (Absolute Values) }\end{array}$ & \multicolumn{2}{l}{ Critical Values } & \multicolumn{1}{l}{$\begin{array}{l}\text { Order of } \\
\text { integration }\end{array}$} \\
\hline Repo rate & -5.4 & -3.54 & -2.93 & -2.60 & $\mathrm{I}(\mathrm{I})$ \\
\multirow{2}{*}{ Lgov } & -1.9 & -3.54 & -2.93 & -2.60 & $\mathrm{I}(0)$ \\
& -2.95 & -3.59 & -2.93 & -2.60 & $\mathrm{I}(\mathrm{I})$ \\
FISC & -0.98 & -3.59 & -2.93 & -2.60 & $\mathrm{I}(0)$ \\
& -5.00 & -3.61 & -2.94 & -2.60 & $\mathrm{I}(\mathrm{II})$ \\
\multirow{2}{*}{ LM3 } & -1.47 & -3.61 & -2.94 & -2.60 & $\mathrm{I}(0)$ \\
\multirow{2}{*}{ LPUB } & -2.44 & -3.61 & -2.94 & -2.60 & $\mathrm{I}(\mathrm{I})$ \\
& -2.94 & -3.61 & -2.93 & -2.60 & $\mathrm{I}(\mathrm{I})$ \\
& -2.31 & -3.61 & -2.94 & -2.60 & $\mathrm{I}(0)$ \\
& -4.27 & 3.63 & 2.95 & 2.61 & $\mathrm{I}(\mathrm{II})$ \\
& 0.3 & -3.63 & -2.95 & -2.61 & $\mathrm{I}(0)$ \\
& -1.59 & -3.63 & -2.95 & -2.61 & $\mathrm{I}(\mathrm{I})$ \\
\hline
\end{tabular}

Source: Author computation

With an automatic lag length selection using Schwarz information criterion (SIC), the results of augmented Dickey-Fuller unit root test reported in the table above indicate that repo rate, government expenditure and broad money are integrated at first difference while fiscal deficit/GDP and public domestic debt are integrated at second difference. To this effect the null hypothesis of non-stationarity is rejected given that the absolute values of $\mathrm{ADF}$ are greater than the critical values at whatever the threshold (i.e 1\%,5\% and 10\%).

\section{Policy Independence in Rwanda}

The coordination between fiscal and monetary policy arises only if the two institutions charged with the respective policies are operationally independent, if moves of one institution depend on the actions of other, then coordination is inherently ensured (Muhammad Farooq Arby et al, 2010). Before I examine the extent of coordination and interaction, it makes sense to test empirically the independence of monetary policy from fiscal policy. 
In this regard, we apply Granger causality test on a combination of monetary and fiscal policy indicators such as repo rate and broad money on one side and fiscal balance ratio to GDP, domestic public debt and government expenditure on the other side. We also explore the existence of co-integration taking into account the aforementioned combination of proxies for the respective policies.

Table 2. Pairwise Granger Causality Tests

\begin{tabular}{lccc}
\hline Null Hypothesis: & Obs & F-Statistic & Prob. \\
\hline LM3 does not Granger Cause FISC & 42 & 1.12651 & 0.3350 \\
FISC does not Granger Cause LM3 & 42 & 0.60408 & 0.5519 \\
REPO does not Granger Cause FISC & 4 & 0.89817 & 0.4160 \\
FISC does not Granger Cause REPO & 42 & 0.72114 & 0.0337 \\
LM3 does not Granger Cause LGOV & & 3.91858 & 0.7459 \\
LGOV does not Granger Cause LM3 & 42 & 11.6291 & 0.0286 \\
REPO does not Granger Cause LGOV & & 0.76783 & 0.0001 \\
LGOV does not Granger Cause REPO & 42 & 0.47700 & 0.6244 \\
LPUB does not Granger Cause LM3 & & 2.72447 & 0.0787 \\
LM3 does not Granger Cause LPUB & 42 & 0.95285 & 0.3949 \\
REPO does not Granger Cause LPUB & 42 & 0.66847 & 0.5186 \\
LPUB does not Granger Cause REPO & & & \\
\hline
\end{tabular}

Source: Author estimation

The results of pair wise Granger causality for different combinations of proxies for monetary and fiscal policies as reported in the table above reveal that generally the indicators for respective policies do not cause one another rather there is unidirectional causality between fiscal balance, repo, money supply and government expenditure. Because there is no bidirectional causality between variables, in this regard, we deduce that monetary policy is operationally independent in Rwanda. This is reflected in the independence with which Rwanda central bank implements its monetary policy.

Table 3. Results of Engle-Granger residual based co-integration

\begin{tabular}{ccccc}
\hline Dependent & Tau-statistic & Prob.* & Z-Statistic & PROB.* \\
\hline REPO & -2.38594 & 0.3458 & -11.7632 & 0.2211 \\
FISC & -2.11844 & 0.4743 & -8.49208 & 0.4216 \\
REPO & -2.14474 & 0.4611 & -9.71139 & 0.3361 \\
LGOV & -1.06916 & 0.8890 & -2.94805 & 0.8793 \\
REPO & -2.20976 & 0.4290 & -10.3856 & 0.2943 \\
LPUB & -0.92939 & 0.9144 & -2.89077 & 0.8830 \\
LM3 & -1.98093 & 0.5437 & -13.4804 & 0.1497 \\
FISC & -2.8923 & 0.1601 & -24.0842 & 0.0082 \\
LPUB & -2.52195 & 0.2875 & -17.2932 & 0.0583 \\
LM3 & -2.47126 & 0.3087 & -15.4331 & 0.0937 \\
LM3 & -3.70611 & 0.0316 & -212.839 & 0.0000 \\
LGOV & -3.79327 & 0.0259 & -245.434 & 0.0000 \\
\hline
\end{tabular}

Source: Author estimations 
The results of single equation residual based Engle-Granger co-integration test presented in the above table also supports the outcome as the null hypothesis of no cointegration is rejected given that $\mathrm{p}$-values for both tau and $\mathrm{z}$ statistics are insignificant implying that there is no co-movement in most of the variable combinations in the long run. However the co-movement exist between M3 and government expenditure respectively, The presence of long run relationship between M3 and government expenditures insinuates that when the government increases its expenditures, this in turn will increase money supply in the different economic agents in turn increase broad money.

\section{Policy Coordination}

Fiscal and monetary policy coordination is considered essential in macroeconomic management. In this respect, coordination exists when both policies respond to a particular macroeconomic challenge in a consistent manner and takes places via various modes such as exchange of information and joint decision making between policy makers from respective institutions. Thus, the VAR approach is used here-under to demonstrate the coordination between monetary and fiscal policy.

Table 5. Vector autoregressive estimates

\begin{tabular}{cccccc}
\hline & FISC & LGOV & LM3 & LPUB & \multicolumn{1}{c}{ REPO } \\
\hline FISC(-1) & 0.904694 & -0.011130 & 0.083829 & -0.081973 & 0.794428 \\
& $(0.09233)$ & $(0.00853)$ & $(0.04103)$ & $(0.04323)$ & $(0.55040)$ \\
& {$[9.79887]$} & {$[-1.30430]$} & {$[2.04297]$} & {$[-1.89632]$} & {$[1.44337]$} \\
\hline LGOV(-1) & -0.544822 & 0.956243 & 0.594116 & -0.250021 & -1.801631 \\
& $(0.39254)$ & $(0.03628)$ & $(0.17446)$ & $(0.18379)$ & $(2.34011)$ \\
& {$[-1.38794]$} & {$[26.3568]$} & {$[3.40549]$} & {$[-1.36038]$} & {$[-0.76989]$} \\
\hline LM3(-1) & 0.159185 & 0.011000 & 0.593761 & 0.223869 & 2.030305 \\
& $(0.26342)$ & $(0.02435)$ & $(0.11707)$ & $(0.12333)$ & $(1.57038)$ \\
& {$[0.60430]$} & {$[0.45182]$} & {$[5.07170]$} & {$[1.81514]$} & {$[1.29288]$} \\
\hline \multirow{2}{*}{ LPUB(-1) } & 0.161178 & 0.016442 & -0.026244 & 0.955198 & -0.276684 \\
& $(0.10850)$ & $(0.01003)$ & $(0.04822)$ & $(0.05080)$ & $(0.64680)$ \\
& {$[1.48554]$} & {$[1.63961]$} & {$[-0.54426]$} & {$[18.8037]$} & {$[-0.42777]$} \\
\hline REPO(-1) & -0.030243 & 0.009356 & -0.010992 & 0.015624 & 0.768401 \\
& $(0.01462)$ & $(0.00135)$ & $(0.00650)$ & $(0.00685)$ & $(0.08717)$ \\
& {$[-2.06830]$} & {$[6.92276]$} & {$[-1.69141]$} & {$[2.28219]$} & {$[8.81507]$} \\
\hline C & 1.396898 & 0.082546 & -0.380898 & 0.013084 & -0.535795 \\
& $(0.67556)$ & $(0.06244)$ & $(0.30024)$ & $(0.31630)$ & $(4.02734)$ \\
& {$[2.06776]$} & {$[1.32203]$} & {$[-1.26863]$} & {$[0.04137]$} & {$[-0.13304]$} \\
\hline
\end{tabular}

Source: Author Estimation

The results of VAR test show, that there is evidence of strong coordination between fiscal and monetary policy. Lagged fiscal deficit affects positively broad money and it is statistically significant. Government expenditure also affects positively money supply and it is statistically significant this is evidenced by how government together with the central bank pursued expansionary policy to stimulate the economic activity. This necessitated both monetary and fiscal authorities to coordinate and raise enough funds to finance the economy thereby pursuing expansionary policies. Therefore, it is clear that there is an evidence of coordination 


\section{Policy interaction in Rwanda}

From the empirical perspective, we test for policy interaction by examining the dynamic impulse responses of selected macroeconomic variables to shocks in either monetary or fiscal policies.

In the context of this study, out of five variables that are taken for analysis, three are fiscal side variables (government expenditure, domestic public debt and budget balance) and two are monetary side variables (Repo rate and broad money). To examine policy interaction we employ unstructured VAR model and this is done by estimating the impulse response functions to obtain the dynamic responses of monetary policy variables in reaction to shocks in fiscal policy and vice-versa.

An important finding is that a positive shock on lagged government expenditure depicts a positive and significant response broad money after three quarters, since our tax revenues cover less of government spending, the Government might use central bank through domestic borrowing via issuance of government securities, obtaining short-term loans such as overdrafts.

These findings are supported by the mechanism of monetary -fiscal coordination that is manifested in constant discussions between the National Bank of Rwanda and the Ministry of Finance and Economic planning through setting of medium term targets for growth and inflation within a technical working group known as Macroframe.

For example in 2008-2009 global financial crisis affected virtually all the economies including Rwanda. Rwanda registered high level of growth but with the highest levels of inflation. To insulate the effects of high inflationary pressures the central bank together with the ministry of finance tightened their policies

Response to Cholesky One S.D. (d.f. adjusted) Innovations \pm 2 S.E.

Response of FISC to LM3
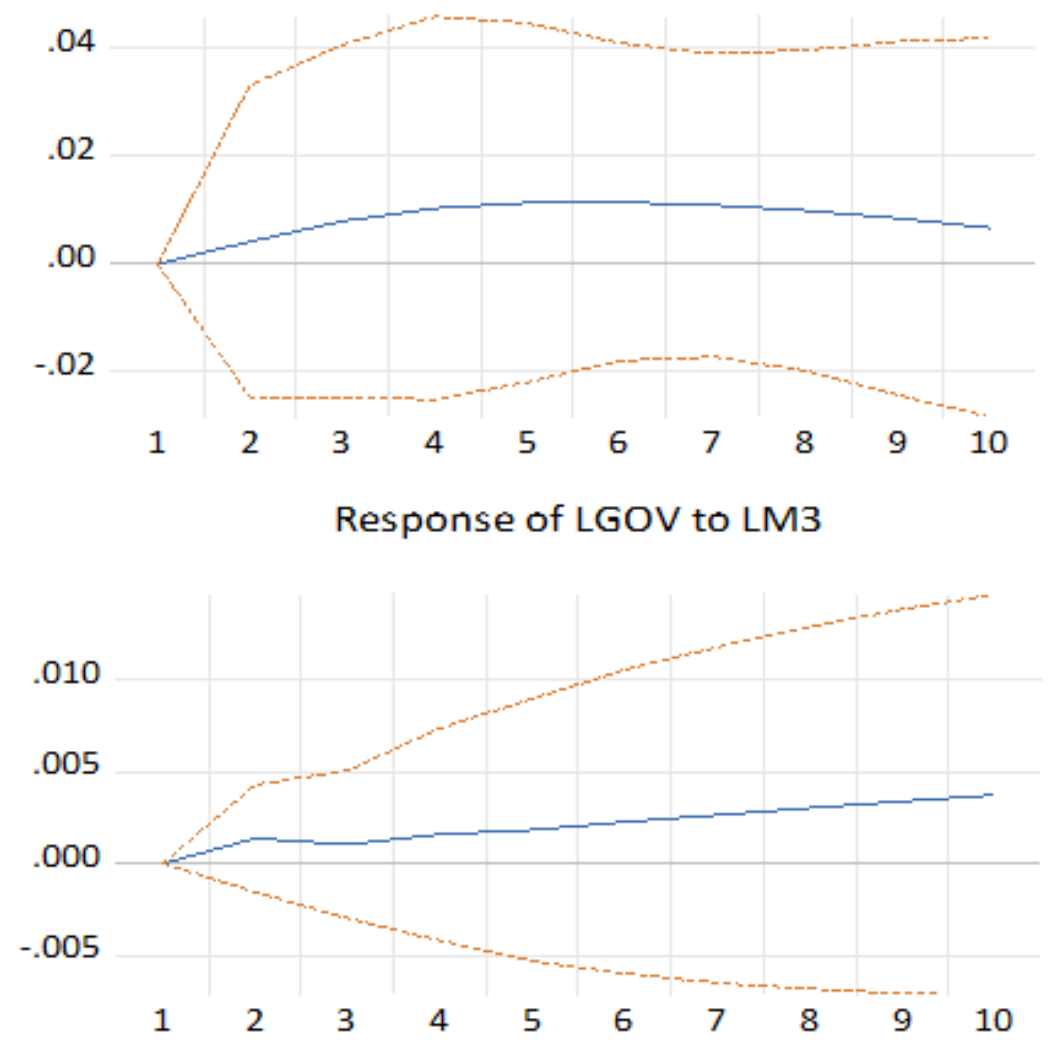


\section{Response of LPUB to LM3}

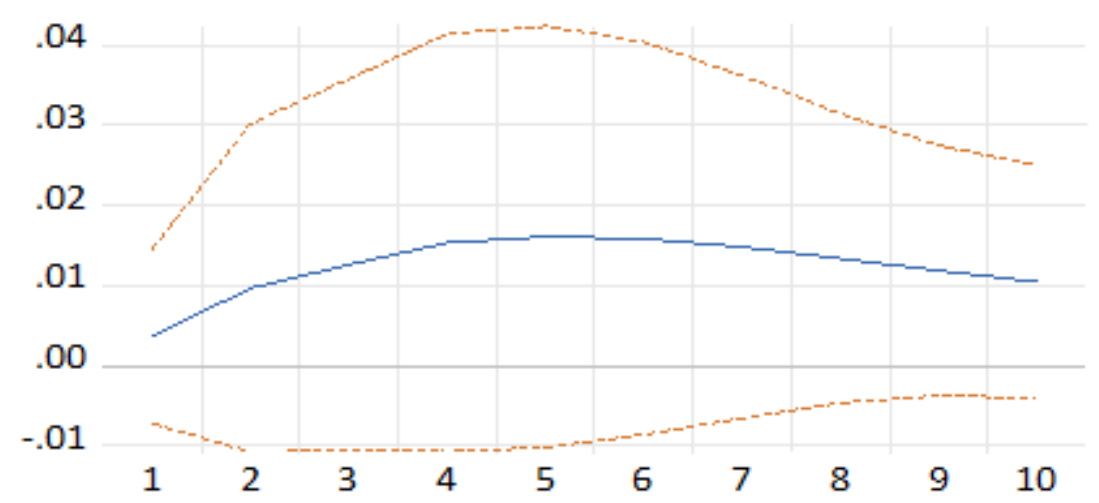

Panel 2. Impulse repose functions to LGOV

Response to Cholesky One S.D. (d.f. adjusted) Innovations \pm 2 S.E.

Response of LM3 to LGOV

.025
.020
.015
.010
.005

$\begin{array}{llllllllll}1 & 2 & 3 & 4 & 5 & 6 & 7 & 8 & 9 & 10\end{array}$

Response of REPO to LGOV

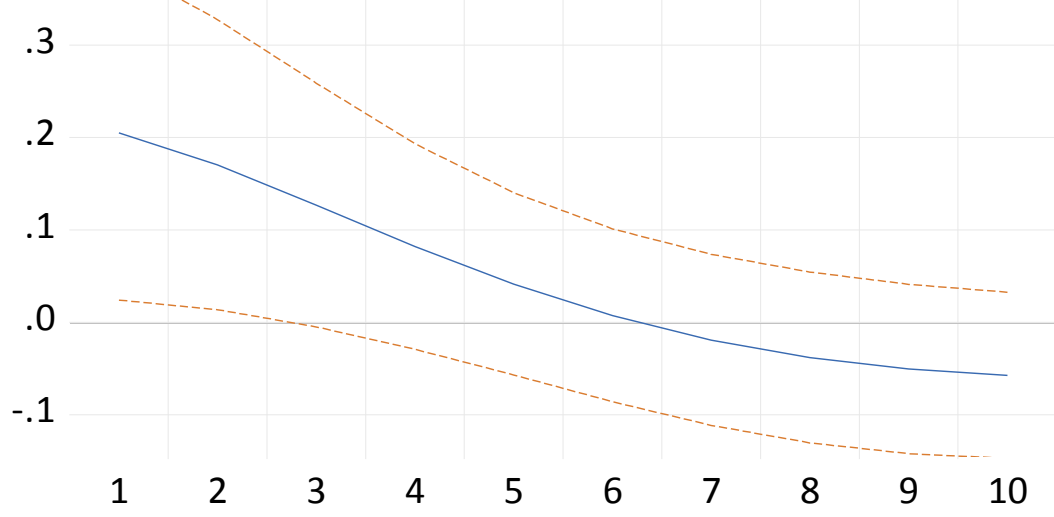


Response to Cholesky One S.D. (d.f. adjusted) Innovations \pm 2 S.E.

Response of FISC to REPO

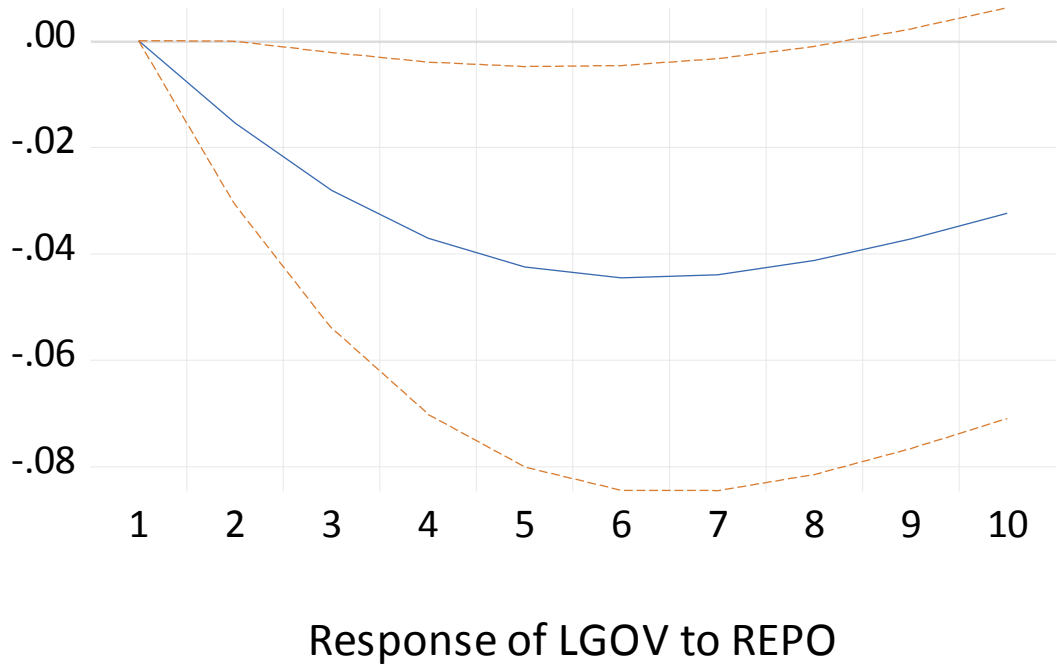

.020

.015

.010

.005

.000

$\begin{array}{llllllllll}1 & 2 & 3 & 4 & 5 & 6 & 7 & 8 & 9 & 10\end{array}$

Response of LPUB to REPO

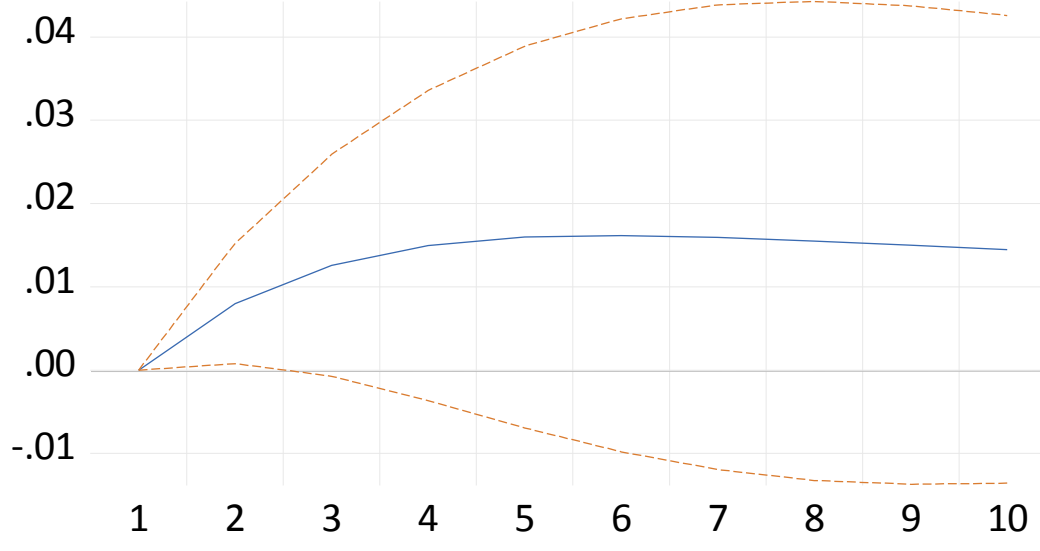


Response to Cholesky One S.D. (d.f. adjusted) Innovations \pm 2 S.E.

Response of LM3 to FISC
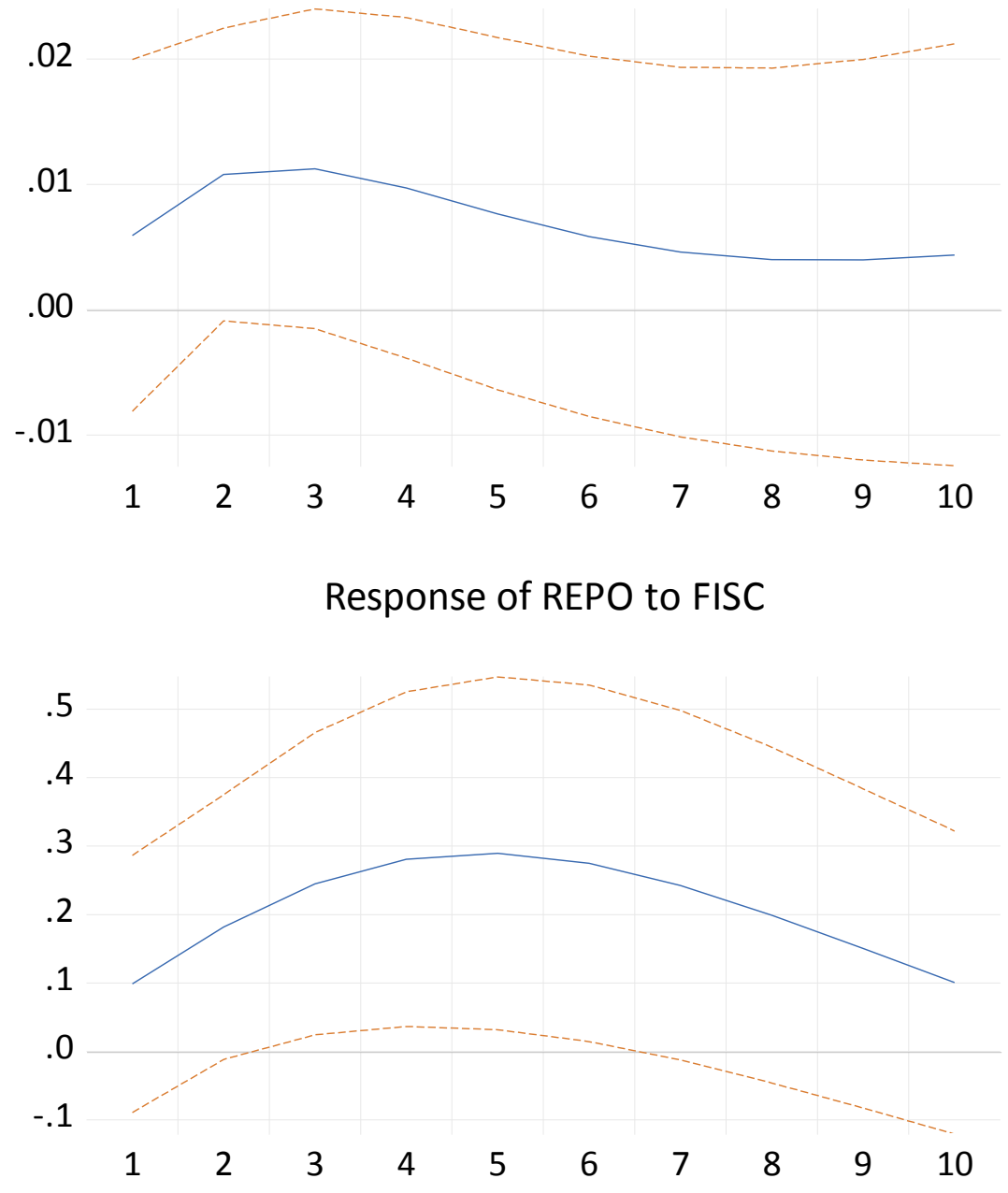

\section{CONCLUSSION}

The coordination between monetary and fiscal policy plays a crucial role in stabilization of the economy therefore, implementation of a sound fiscal policy creates room for an active monetary policy. This paper employs quarterly data to explore the monetary-fiscal policy coordination in Rwanda between the period 2008Q1-2018Q4. We employed government expenditure, fiscal deficit per GDP and public domestic debt as fiscal policy proxies while broad money and repo rate were used as monetary policy proxies. Tests from granger causality revealed the independence of central bank from fiscal policies, The results of the VAR model showed the evidence of coordination between Rwandan fiscal and monetary policy where by tests revealed in this period both central bank and government pursued expansionary policies to stimulate the economy activities.

The findings from the study revealed that there is an evidence of policy coordination of the two institutions, Further; the paper analyzes the interactions between monetary and fiscal policies using VAR approach through estimating dynamic impulse response functions (IRF) to provide policy interaction. 


\section{REFERENCES}

Andlib et al. (2012). fiscal and monetary policy coordination in Pakistan.

Arby Farooq and Muhammad Nadeem Hanif (2010). Monetary and Fiscal Coordination: Pakistan's Experience. SBP Research Bulletin.

Blinder, Alan S. (1998). "Issues in the Coordination of Monetary and Fiscal Policies". NBER Working Paper Series.

Haleim, Sahar Mohammed Abdel. (2016). Coordination of Monetary and Fiscal Policies: The Case of Egypt. International Review of Research of Emerging Market Economies and the Global Economy.

Ministry of Finance and Economic Planning (2007). Economic Development \& Poverty Reduction Strategy 2008-2012. Kigali

Muscatelli, V., A. PatrizioTirelli, and C.Trecroci (2002). Monetary and Fiscal Policy Interactions Over the Cycle. Some Empirical Evidence.

Nordhaus, W. D. (1994). Policy games: Coordination and independence in monetary and fiscal policies. Brookings papers on economic activity.

Sargent, T.J., \& Wallace N. (1981). Rational expectations, the optimal monetary instrument, and the optimal money supply rule. Journal of Political Economy 83: 241254.

Shabbir, T. \& Ahman A. (1994). Are government deficits inflationary? Evidence from Pakistan. Pakistan development review.

Semmler, W., and Zhang. W. (2003). Monetary and fiscal policy interactions. Some empirical evidence from the Euro-Area.

Tarawalie, Abu Bakarr, Momodu Sissoho, Mohamed Conte, and Christian R. Ahortor. (2013). Fiscal and Monetary Theoretic Analysis. UCLA Working Paper No. 368.

Zoli E. (2005). How Does Fiscal Policy Affect Monetary Policy in Emerging Market Countries. BIS Working Papers 174, Bank for International Settlements. 